\title{
A Note on Manganese in Marine Plankton.
}

\author{
By
}

\author{
L. H. N. Cooper,
}

Assistant Chemist at the Plymouth Laboratory.

\begin{abstract}
Although to many organisms manganese is known to be of great importance (Berkeley, 1922; Brenchley, 1927; Hopkins, 1930) its part in the economy of the sea is unknown. Some attempts were therefore made in 1934 to estimate the manganese in marine plankton using the residues from the determinations of phosphorus (Cooper, 1934; Harvey et alia, 1935). The residues from the triplicate digests from each cruise were combined and concentrated from about 200 to $70 \mathrm{ml}$. The concentrates were then examined quantitatively for manganese by the periodate method of Willard and Greathouse as described by Yoe (1928). In all cases but one the concentration of manganese was less than could be detected with certainty (Table I). In the absence of confirmatory data the figure of $5 \gamma$ per litre of the diatom catch of May 15th must be regarded as suspect and attributable to chance contamination. Thus in these catches at L4 (5 miles off shore) during the spring outburst in 1934 manganese amounted to less than three parts per million million parts of water filtered, equivalent to one-thousandth or less of the phosphorus content.
\end{abstract}

\section{TABLE I.}

Manganese content of plankton caught at Station L4. First group caught with quantitative net; second group with ordinary tow-nets. The diatoms of May 15th and 24th were separated from the larger animals by passage through a silk net having 60 meshes to the linear inch.

\begin{tabular}{|c|c|c|c|c|c|c|}
\hline $\begin{array}{l}\text { Date } \\
1934 .\end{array}$ & $\begin{array}{l}\text { Descrip } \\
\text { plank }\end{array}$ & $\begin{array}{l}\text { tion of } \\
\text { ton. }\end{array}$ & & & $\begin{array}{c}\text { Manganese } \\
\text { in catch } \\
\gamma / \mathrm{m}^{3} \text {. of sea } \\
\text { water filtered. }\end{array}$ & $\begin{array}{c}\text { Ratio } \\
\text { Mn/P } \\
\text { (weight/ } \\
\text { /weight). }\end{array}$ \\
\hline $9 / 3$ & Routine haul; & mixed & . & . & $<3$ & $<0.003$ \\
\hline $10 / 5$ & ," & , & . & . & $<1$ & $<0.0008$ \\
\hline $15 / 5$ & , & , & . & . & $<2$ & $<0.002$ \\
\hline $23 / 5$ & , & ," & . & . & $<0.5$ & $<0.002$ \\
\hline $10 / 5$ & Fæcal pellets & . & 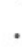 & . & $<0.3$ & $<0.02$ \\
\hline $4 / 5$ & \multicolumn{2}{|c|}{ Animal plankton } & & . & $\begin{array}{c}\gamma / \text { litre of catch. } \\
\quad<0 \cdot 2\end{array}$ & $<0.0008$ \\
\hline $15 / 5$ & Diatoms . & . & . & $\cdot$ & ca 5 (?) & ca 0.01 \\
\hline $24 / 5$ & Rhizosolenia s] & op. & . & . & $<2$ & $<0.02$ \\
\hline
\end{tabular}




\section{REFERENCES.}

Berkeley, C. 1922. On the Occurrence of Manganese in the Tube and Tissues of Mesochatopteros Taylori, Potts and in the Tube of Chatopteros variopedatus, Renier. Biochem. Journ. Vol. XVI, p. 70.

Brenchley, W. E. 1927. Inorganic Plant Poisons and Stimulants. Chapter VII. Cambridge.

Cooper, L. H. N. 1934. The Determination of Phosphorus and Nitrogen in Plankton. Journ. Mar. Biol. Assoc., N.S., Vol. XIX, pp. 755760 .

Harvey, H. W., Cooper, L. H. N., Lebour, M. V., and Russell, F. S. 1935. Plankton Production and its Control. Journ. Mar. Biol. Assoc., N.S., Vol. XX. No. 2.

Hopkins, E. F. 1930. Necessity and Function of Manganese in the Growth of Chlorella sp. Science, Vol. 72, pp. 609-610.

Yoe, J. H. 1928. Photometric Chemical Analysis. Vol. I. Colorimetry, pp. 273-279. 